\title{
Climate Change and Security
}

\author{
Francesco Sindico*
}

Ten years ago, in the very first issue of Carbon and Climate Law Review (CCLR), I discussed the question of whether climate change was becoming a security issue and whether it belonged within the scope of the United Nations Security Council (UNSC). ${ }^{1}$ The first issue of CCLR was published on the backdrop of the first ever debate before the UNSC on the impacts of climate change on international security, which took place on 17 April 2007, and just a few years after the release in 2004 of the High-Level Panel on Threats, Challenges and Change report that included environmental degradation as a possible threat to international security. ${ }^{2}$ In that article, I argued that three factors had led climate change before the UNSC: the leadership of the United Kingdom in this specific area of climate diplomacy, the changing nature of security from international to human security, ${ }^{3}$ and a greater emphasis on sustainable development and conflict prevention. I then went on to discuss whether the UNSC was indeed the right place to be discussing climate change. Countries were very much divided at the time. On the one hand, several developed countries and small-island developing states (SIDS) were in favour of giving the UNSC a role in dealing with climate change, but even there one could appreciate differences. Developed countries saw the 'securitisation' of climate change as a way to raise the stakes and increase global awareness.

* Francesco Sindico, Co-Director of the Strathclyde Centre for Environmental Law and Governance. For Correspondence: $<$ francesco.sindico@strath.ac.uk>. DOI: $10.21552 / \mathrm{cclr} / 2017 / 3 / 6$

1 Francesco Sindico, 'Climate Change: A Security (Council) Issue?' (2007) 1(1) Carbon and Climate Law Review 26-31.

2 United Nations, A More Secure World: Our Shared Responsibility (Report of the Secretary General's High-Level Panel on Threats, Challenges and Change, 2004).

3 Michael R Redclift, David Manuel-Navarrete and Mark Pelling, Climate Change and Human Security: The Challenge to Local Governance under Rapid Coastal Urbanization (Edward Elgar Publishing 2011).

4 UNGA Resolution 63/281, 3 June 2009.

5 ibid, para 2.

6 United Nations, Climate change and its possible security implications (Report of the Secretary General, Doc A/64/350, 11 September 2009).
SIDS pursued a much more active role of the UNSC, maintaining that climate change was already a security issue for them. On the other hand, most developing countries did not see favourably the involvement of the UNSC. They considered that climate change should have been dealt with more global institutions, such as the UN General Assembly and the international climate change legal regime itself.

Ten years later, the celebration of CCLR's anniversary provides us with an opportunity to briefly discuss the extent to which climate change has indeed become a security issue and whether the UNSC itself has taken a greater role. I will first review whether climate change has indeed been further discussed before the UNSC, or has even been included in any of its Resolutions. I will then move on to discuss whether in the past ten years climate change has been linked to other factors that could lead to a threat to peace and international security. Finally, I will highlight some international legal questions (outside of the UNSC) that stem from the securitisation of the climate change discourse.

The discussion in 2007 at the UNSC on climate change was not an isolated event. It was followed by a meeting in 2011, two in 2015 and a further one in April 2017. These meetings have followed the Arria formula, meant to encourage more informal discussions that do not necessarily lead to the adoption of formal documents, hence giving countries more space to voice their positions and concerns. Stemming from such discussions the UN General Assembly adopted in 2009 a Resolution on 'Climate change and its possible security implications', ${ }^{4}$ which mandated the Secretary General to submit a report on the topic of climate change and security, ${ }^{5}$ which was published later the same year. ${ }^{6}$ Rather than providing a clear indication as to whether climate change is indeed to be considered a threat to peace and international security, and far from clarifying a potential role for the UNSC, these meetings have, over the last decade, provided space for soft power and climate diplomacy to push climate change higher on the UNSC agenda as a 'threat multiplier'. And that is precisely what climate change is and should be consid- 
ered. Climate change per se is no threat to peace and international security, but its negative effects, when coupled with other factors that lead to conflicts and violence, can make a situation, literally, explosive. An example of this approach comes from Lake Chad. The UNSC organised a visit to the region in March 2017, which ended with a statement by Mr Rycroft, the UK President of the UNSC at the time, who framed the causes of tension and conflict in the region in the following way: 'Those are multifaceted, complex set of problems and require a holistic set of solutions.' Amongst these multifaceted challenges 'drought and other environmental challenges' were singled out. ${ }^{7}$ That same month, UNSC Resolution 2349 (2017) on the Lake Chad refers to climate change in the following terms:

Recognizes the adverse effects of climate change and ecological changes among other factors on the stability of the region, including through water scarcity, drought, desertification, land degradation, and food insecurity, and emphasizes the need for adequate risk assessments and risk management strategies by governments and the United Nations relating to these factors; ${ }^{8}$

Only 10 years after the first meeting discussing climate change before the UNSC, the latter has adopted a legally binding Resolution where it did not shy away from mentioning climate change and its adverse effects as one of the 'roots causes' of a conflict, in this case the tension and violence in the Lake Chad region. Interestingly, it does not limit itself to stating that climate change is a threat multiplier, but it takes a further step and encourages countries and the UN to step up its efforts in terms of 'risk assessment' and 'risk management' strategies. I will show how this last recommendation may well be a potential link with the current international climate change legal regime.

But before I get there, let us pause and reflect as to whether the past ten years have proved that climate change is indeed a threat multiplier leading to threats to peace and international security. One of the major conflicts of the last ten years has been increasingly linked to climate change. According to some authors, the apparent sectarian and political nature of the Syrian conflict also hides causes directly linked to climate change. ${ }^{9}$ In 2006, the worse drought in centuries paved the way for unrest in already crowded cities. Water shortages and rise in food prices increased tensions and led to violence within the cities where the unrest and the civil war started. Moving to the African continent, a UNEP report links climate change to the violent conflict in Darfur. Water scarcity and crops decline in productivity were hailed as many of the factors exacerbating the already existing tensions. ${ }^{10}$ Talking about the Darfur conflict, former UN Secretary General Ban KiMoon referred to it in the following way: 'Amid the diverse social and political causes, the Darfur conflict began as an ecological crisis, arising at least in part from climate change. ${ }^{11}$ And on the Arab peninsula, water and climate change have been said to be at the heart of the ongoing conflict in Yemen. ${ }^{12}$ Further studies have highlighted the relationship between extreme climatic conditions and unrest in countries and regions, such as Afghanistan, Somalia and Northern Africa. The same study concludes by maintaining that 'natural disasters had the potential to amplify already existing societal tensions and ... thus to further destabilise several of the world's most conflict-prone regions. ${ }^{13}$ It would be difficult to argue that these past and current conflicts are directly linked to climate change, but the past decade has proven that climate change and its negative effects, water scarcity in particular, pose a considerable threat multiplier to countries that are already prone to tension for other non-environmental reasons.

This short piece has showed that in the last ten years the UNSC has continued to address climate change as a security issue and has recently even included it in a Resolution as one of the root factors of

7 'Security Council wraps up Lake Chad Basin visit; stops in "epicentre" of Boko Haram violence' (UN News Centre, 6 March 2017) <http://www.un.org/apps/news/story.asp?NewsID=56298 \#.WYi3FoTyvIW> accessed 17 August 2017.

8 UNSC Resolution 2349 (2017), para 26 <https://www.un.org/ press/en/2017/sc12773.doc.htm> accessed 17 August 2017.

9 Peter $\mathrm{H}$ Gleick, 'Water, Drought, Climate Change, and Conflict in Syria' (2014) 6 AMS 331-340.

10 United Nations Environment Programme, 'Synthesis Report Sudan Post-Conflict Environmental Assessment' (2007) <http:// postconflict.unep.ch/publications/UNEP_Sudan_synthesis_E.pdf> accessed 17 August 2017

11 'Darfur conflict heralds era of wars triggered by climate change, UN report warns' The Guardian (23 June 2017).

12 Collin Douglas, 'A Storm Without Rain: Yemen, Water, Climate Change, and Conflict' (Center for Climate \& Security, 3 August 2016) < https://climateandsecurity.org/2016/08/03/a-storm -without-rain-yemen-water-climate-change-and-conflict/> accessed 17 August 2017.

13 'Climate change increases the risk of war, scientists prove' The Independent (25 July 2016). 
a conflict. A brief overview of tensions and violence over the past decade, from Syria to Yemen and beyond, confirms climate change as a threat multiplier. Notwithstanding these developments that seem to align climate change with security, the role of the UNSC and the response it can take to deal with climate change is still unclear. ${ }^{14}$ It is hence necessary to better understand whether the securitisation of the climate discourse has opened up new legal opportunities or raised new legal challenges outside of the UNSC. I will briefly touch upon three of these legal questions: international litigation, climate refugees, and loss and damage.

Firstly, international litigation on climate change and litigation has always been linked to SIDS making usually an emotional case around a potential climate change. ${ }^{15}$ In 2011, Palau considered strategies leading to a request for an advisory opinion from the International Court of Justice. ${ }^{16}$ While there is evidence that climate change is leading to negative effects that may cause (in the worst case scenarios) the disappearance of SIDS, it is much more difficult to develop a solid legal argument capable of dealing with the hurdles of causation and state responsibility. Ironically, the adoption of the Paris Agreement, hailed by many as a major (positive) milestone in international climate law, may make it even more difficult for SIDS and any other interested States to bring a case

14 See Shirley Scott, 'Implications of climate change for the UN Security Council: mapping the range of potential policy responses' (2015) 91(6) International Affairs 1317-1333 and Shirley Scott and Charlotte Ku, Climate Change and the UN Security Council (Edward Elgar Publishing, forthcoming).

15 Michael Gerrard and Gregory Wannier, Threatened Island Nations: Legal Implications of Rising Seas and a Changing Climate (Cambridge University Press 2013).

16 Palau seeks UN World Court opinion on damage caused by greenhouse gases, 22 September 2011, UN News Centre <http:// www.un.org/apps/news/story.asp?NewsID $=39710 \& C r$ $=$ pacific + island $\& C r 1=\# . W Y j h 40$ TyvlU $>$ accessed 17 August 2017.

17 At a domestic level things are very different, with the Paris Agreement paving the grounds for potentially much more climate change litigation.

18 Frank Biermann and Ingrid Boas, 'Preparing for a warmer world: Towards a global governance system to protect climate refugees' (2010) 10(1) Global Environmental Politics 60-88

19 'Kiribati climate change refugee told he must leave New Zealand' The Guardian (22 September 2015) < https://www.theguardian com/environment/2015/sep/22/kiribati-climate-change-refugee -told-he-must-leave-new-zealand> accessed 17 August 2017.

20 Meinhard Doelle, 'The Birth of the Warsaw Loss \& Damage Mechanism' (2014) 8(1) Carbon and Climate Law Review 35-45.

21 Paris Agreement, art 8.

22 UNSC Resolution 2349 (2017) (n 9) para 26. before an international court due to the programmatic and non-enforceable nature of the provisions laid in the Paris Agreement. ${ }^{17}$ Framing climate change as a security issue does not really aid in terms of international climate change litigation. However, it does amplify the stakes and opens up policy space due to the high-level nature of security debates globally.

Secondly, the greater the link between climate change and conflict and security, the stronger the call to look afresh to the legal definition of refugees in order for it to include climate refugees. ${ }^{18}$ In 2015 , this issues left the pages of academic commentary and landed on mainstream media after a national from Kiribati, who claimed asylum on climate change grounds, was sent back home from New Zealand. ${ }^{19}$ Despite climate change becoming more real in SIDS and other fragile developing countries, it will be difficult for courts in any country to grant refugee status without official international legal recognition of climate refugees. Until then, people leaving countries prone to climate change negative effects may be easily assimilated to economic migrants and not be granted asylum. A different scenario may present itself if the country is not only prone to negative climate change effects, but has been hit by a climate change related natural disaster, which may have even increased tensions within that country. The lines between economic migrant and climate refugee may well be blurred in such a scenario partly due to the securitisation of the climate discourse.

Thirdly, and very much linked to those cases when a country suffers sudden damages and great losses because of climate change, is the debate around the concept and now provision of 'loss and damage' within the international climate change legal regime. ${ }^{20} \mathrm{It}$ could be speculated that one of the results of framing climate change (also) as a security issue in this past ten years has been the inclusion of a stand-alone provision in the Paris Agreement on loss and damage. ${ }^{21}$ Having said that, the provision and its current implementation and follow up is probably a watered down version from that advocated by those who were hoping to develop a legal mechanisms capable of providing direct monetary compensation for the loss and damages caused by climate change through a fund paid into by the greatest world polluters. Loss and damage is, instead, very much a clearing house of good practices related to 'adequate risk assessments and risk management strategies by governments and the United Nations.22 I deliberately use the wording 
of the March 2017 UNSC on the Lake Chad to emphasise a possible area of collaboration between the UNSC itself and the international climate change legal regime.

In sum, while the securitisation of the climate discourse may have sparked greater attention to possible cases of international litigation and to debates over widening the definition of refuges to climate refugees, the extent to which framing climate change as a security issue has been able to provide clarity to the legal questions underpinning climate change and litigation and climate change refugees is highly debatable. On the other hand, collaboration between the UNSC and the international climate change legal regime in the field of loss and damage seems more promising.

In conclusion, the last decade has shown an increased level of activity within the UNSC in the field of climate change. The linkage between climate change and security has been enshrined in a March 2017 UNSC resolution on the Lake Chad. Furthermore, global geo-political tensions can be indirectly linked to negative effects of climate change, especial- ly in countries and regions that were already prone to conflict. Against this background, the role of the UNSC in dealing with climate change is still unclear and an area where more work is needed. The collaboration between the UNSC and the international climate change legal regime in the field of loss and damage could be one way of moving forward. Ongoing negotiations aimed at further operationalising the provision on loss and damage should be shared with the UNSC. At the same time, at the next meeting of the UNSC on climate change loss and damage, experts should be invited to explore how the UNSC can contribute positively to identifying and promoting 'adequate risk assessments and risk management strategies by governments and the United Nations'. More research and more work on the ground paving the way for this potentially fruitful collaboration should be undertaken before the next UNSC debate on climate change. While we cannot be sure of the results of such collaboration, what we can be sure of is that CCLR will be there, as it has been in the past ten years, to monitor and analyse the relationship between climate change and security. 